\title{
Hubungan Kualitas Tidur dengan Kejadian Dismenore Primer pada Mahasiswi Fakultas Kedokteran Universitas Islam Bandung
}

\author{
Richi Delistianti Y, ${ }^{1}$ Siska Nia Irasanti, ${ }^{2}$ Ferri A.F.M, ${ }^{3}$ \\ R. Ganang Ibnusantosa, ${ }^{4}$ Wawang S. Sukarya ${ }^{5}$ \\ ${ }^{1}$ Program Studi Pendidikan Dokter, ${ }^{2,4}$ Departemen Ilmu Kesehatan Masyarakat, \\ 3.5 Departemen Obstetri dan Ginekologi \\ Fakultas Kedokteran, Universitas Islam Bandung
}

\begin{abstract}
Abstrak
Mayoritas mahasiswi Fakultas Kedokteran memiliki kualitas tidur yang buruk. Hal tersebut dihubungkan dengan sistem pendidikan di Fakultas Kedokteran yang sangat ketat dan waktu belajar yang tidak sebentar diduga menyebabkan kualitas tidur buruk pada mahasiswi. Beberapa penelitian menyatakan kualitas tidur dapat dihubungkan dengan patogenesis nyeri, termasuk dismenore primer. Kejadian dismenore primer pada perempuan juga dapat terjadi pada mahasiswi Fakultas Kedokteran Universitas Islam Bandung. Penelitian ini bertujuan mengetahui hubungan kualitas tidur dengan angka kejadian dismenore primer pada mahasiswi Fakultas Kedokteran Universitas Islam Bandung periode Maret-Mei 2018. Jenis penelitian adalah analitik observasional dengan pendekatan cross-sectional. Subjek dipilih secara systematic random sampling dan didapatkan 106 sampel. Tiaptiap responden menandatangani informed concent, kuesioner pittsburgh sleep quality index (PSQI), dan kuesioner numerical rating scale (NRS). Data dianalisis menggunakan program Epi Info 7 . Hasil penelitian $62 \%$ memiliki kualitas tidur buruk, 49\% dismenore primer sedang, 10\% dismenore primer berat. Angka kejadian dismenore sedang pada kelompok subjek kualitas tidur buruk lebih besar daripada kualitas tidur baik, secara statistik perbedaan ini sangat bermakna $(\mathrm{p}=0,008)$. Angka kejadian dismenore berat pada kelompok subjek kualitas tidur buruk lebih besar daripada kualitas tidur baik, secara statistik perbedaan ini bermakna $(\mathrm{p}=0,04)$. Simpulan, terdapat hubungan kualitas tidur dengan kejadian dismenore primer pada mahasiswi Fakultas Kedokteran Universitas Islam Bandung.
\end{abstract}

Kata kunci: Dismenore primer, fakultas kedokteran, kualitas tidur

\section{Relation Between Sleep Quality and Primarry Dysmenorrhea on Medical Students of Bandung Islamic University}

\begin{abstract}
Majority of medical students have poor sleep quality, related to the system of medical education which is very strict and long time study causing of poor sleep quality to the students, including female students. Some studies suggest that sleep quality may be associated with pathogenesis of pain, such as primarry dysmenorrhea. The incidence of primarry dysmenorrhea can also increase on students of Medical Faculty of Bandung Islamic University. The study aims to determine the relation between the quality of sleep and the incidence of dysmenorrhea in period MarchMay 2018. The type of research is analytic observational study with cross-sectional approach. The subjects were chosen by systematic random sampling and obtained 106 samples. Respondents fill out each informed consent, questionnaire pittsburgh sleep quality index (PSQI), and questionnaire numerical rating scale (NRS). Data were analized using Epi Info 7. The results of this study showed that $62 \%$ of female students had have poor sleep quality, $49 \%$ moderate primary dysmenorrhea, $10 \%$ severe primary dysmenorrhea. The incidence of moderate primarry dysmenorrhea on the subject poor sleep quality are greater than good sleep quality, has very statistically significant different $(\mathrm{p}=0.008)$. On the subjects with poor sleep quality, the incidence of severe primarry dysmenorrhea were found to be statistically significant $(\mathrm{p}=0.04)$. In conclusion there is a statistically significant relation between sleep quality and the incidence and degree of primary dysmenorrhea.
\end{abstract}

Keywords: Faculty of medicine, prymary dysmenorrhea, sleep quality

Korespondensi: Richi Delistianti Y. Program Studi Pendidikan Dokter. Alamat: Jl. Tamansari No.20, Bandung 40116, Provinsi Jawa Barat Telepon: 0224203368 Faksimile: 0224203368 HP: 085860223350 Email : richidelistianti@yahoo.co.id 


\section{Pendahuluan}

Menstruasi adalah proses fisiologis normal yang terjadi kira-kira sekali dalam sebulan pada wanita usia subur akibat meluruhnya jaringan endometrium. ${ }^{1}$ Kebanyakan wanita mengalami tingkat nyeri dan kesulitan tertentu selama dalam periode menstruasi. Dismenore merupakan keluhan yang paling umum dilaporkan. ${ }^{2}$ Dismenore adalah masalah ginekologi yang paling umum terjadi di kalangan wanita dan didefinisikan sebagai nyeri kram pada perut bagian bawah yang terjadi sebelum atau selama menstruasi. ${ }^{3}$ Dismenore primer merupakan beban kesehatan bagi wanita. Diperkirakan setiap jam, 140 juta wanita absen dari sekolah maupun pekerjaan karena dismenore. ${ }^{4}$

Berbagai faktor risiko yang berhubungan dengan dismenore primer antara lain usia dewasa muda, menarch awal, indeks massa tubuh tinggi atau rendah, paritas, merokok, siklus haid yang berkepanjangan, aliran menstruasi tidak teratur, gejala pramenstruasi, kecurigaan klinis terhadap penyakit radang panggul, serta gejala psikologis seperti depresi dan kecemasan. ${ }^{5}$

Menurut World Health Organization (WHO) didapatkan kejadian dismenore itu sebesar 90\%. ${ }^{6}$ Prevalensi yang lebih besar umumnya terjadi pada wanita muda dengan perkiraan $67-90 \%$ berusia $17-$ 24 tahun. Dismenore primer pada umumnya terjadi pada remaja dan $>50 \%$ wanita menstruasi di dunia melaporkan menderita dismenore primer. ${ }^{7}$ Data dari Pelayanan Kesehatan Peduli Remaja (PKPR) dan puskesmas menunjukkan bahwa gangguan menstruasi di Kota Bandung menduduki peringkat tertinggi, yaitu $73 \%$ data puskesmas dan $82 \%$ data PKPR disusul oleh masalah penyakit menular seksual sebanyak $8 \%$ dan konsultasi $\mathrm{KB}$ sebanyak $4 \%{ }^{8}$

Dismenore primer dapat berdampak terhadap kualitas hidup seorang wanita dan menyebabkan nyeri panggul spesifik yang dapat mengganggu aktivitas. ${ }^{9}$ Penelitian Gebeyehu dkk. ${ }^{10}$ menjelaskan dampak yang sering dikeluhkan seperti ketidakhadiran sekolah, konsentrasi yang buruk, gangguan tidur, perubahan perilaku, dan pembatasan aktivitas sehari-hari.

Dismenore primer itu disebabkan oleh induksi prostaglandin yang akan menyebabkan rahim menjadi berkontraksi. ${ }^{11}$ Pelepasan prostaglandin diduga berasal dari sel yang terpecah selama pelepasan endometrium diyakini menyebabkan hiperkontraktilitas miometrium terjadi iskemia dan hipoksia otot rahim sehingga menimbulkan rasa sakit serta gangguan kualitas tidur. ${ }^{12}$ Finan dkk. ${ }^{13}$ dalam penelitiannya mendapatkan bahwa kualitas tidur dihubungkan dengan intensitas dan rasa sakit.

Kualitas tidur adalah takaran kebiasaan baik dan buruk tidur seseorang. Kualitas tidur yang buruk dan gejala insomnia dikaitkan dengan kesehatan yang buruk, ketidakhadiran kerja, dan peningkatan risiko gangguan jiwa, termasuk depresi. ${ }^{14}$ Survei di Lituania membandingkan para mahasiswa kedokteran dengan mahasiswa hukum dan ekonomi, mendapatkan bahwa lebih dari separuh mahasiswa yang mendapat nilai >5 ada Pittsburg Sleep Quality Index (PSQI) 59,4\% memiliki kualitas tidur yang buruk..$^{15}$

Penelitian Woosley dan Lichstein ${ }^{16}$ yang dilakukan pada wanita usia reproduktif dapat menjelaskan bahwa wanita yang memiliki riwayat insomnia memiliki derajat nyeri dismenore lebih berat daripada yang tidak. Selama ini, di Universitas Islam Bandung khususnya di Fakultas Kedokteran Universitas Islam Bandung belum pernah dilakukan penelitian tentang hubungan kualitas tidur dengan dismenore primer. Pemilihan dilaksanakan terhadap mahasiswa kedokteran sebagai subjek penelitian dikarenakan usia pada mahasiswi merupakan usia yang rentan terjadi dismenore. Sistem pendidikan di fakultas kedokteran yang sangat ketat dan waktu belajar yang tidak sebentar diduga dapat menyebabkan kualitas tidur yang tidak baik. Kejadian dismenore primer pada perempuan juga dapat terjadi pada mahasiswa Fakultas Kedokteran Universitas Islam Bandung yang mayoritas terdiri atas perempuan.

Tujuan penelitian ini adalah mengetahui hubungan kualitas tidur dengan angka kejadian dismenore primer pada mahasiswi Fakultas Kedokteran Universitas Islam Bandung tahun ajaran 2017/2018.

\section{Metode}

Penelitian ini dilaksanakan di Fakultas Kedokteran Universitas Islam Bandung pada bulan Maret-Mei 2018, diawali dengan pemilihan kriteria responden secara systematic random sampling dengan kriteria inklusi mahasiswi tingkat 3 Fakultas Kedokteran Universitas Islam Bandung dan tidak sedang hamil. Kriteria eksklusi adalah mahasiswi yang waktu penelitian dilakukan tidak hadir dan sedang mengonsumsi obat-obatan karena gangguan tidur atau penyakit lain yang berpengaruh terhadap kualitas tidur seperti asma, gagal jantung, dan penyakit tiroid. Jumlah sampel yang didapat sebanyak 106 orang.

Kuesioner kualitas tidur diukur mempergunakan Pittsburgh Sleep Quality Index (PSQI). Kuesioner tersebut mengukur kualitas tidur individu dilihat dari 2 kategori, yaitu baik $<7$ dan buruk $\geq 7$. Kuesioner dismenore primer diukur menggunakan kuesioner numerical rating scale (NRS) dengan 3 kategori, yaitu ringan $1-3$, sedang $4-6$ dan berat $7-10$.

Penelitian ini mempergunakan metode analitik dengan pendekatan cross-sectional. Data dianalisis mempergunakan uji chi-square. Pengujian dilakukan menggunakan taraf kemaknaan 5\% ( $\alpha=0,05)$. Hubungan antara kualitas tidur dan kejadian dismenore primer disimpulkan bermakna jika nilai $\mathrm{p}<\alpha$. Data yang diperoleh diolah dengan menggunakan program Epi Info 7.

Penelitian ini sudah mendapat persetujuan etik oleh Komite Etik Penelitian Kesehatan Fakultas Kedokteran Universitas Islam Bandung dengan Nomor: 255/Komite Etik.FK/III/2018.

\section{Hasil}

Sebagian besar subjek memiliki kualitas tidur buruk, yaitu sebanyak 62\%. Hasil pengukuran dismenore primer telah dihitung dengan menggunakan kuesioner numerical rating scale (NRS) pada mahasiswi tingkat 3 Fakultas Kedokteran Universitas Islam Bandung tahun ajaran 2017-2018. Sebagian besar subjek menderita dismenore primer sedang $49 \%$ dan dismenore primer berat sebanyak $10 \%$. 
Hasil perhitungan skor kualitas tidur menggunakan Pittsburgh Sleep Quality Index (PSQI) pada mahasiswi tingkat 3 Fakultas Kedokteran Universitas Islam Bandung dapat dilihat pada Tabel 1:

Tabel 1 Distribusi Subjek berdasar atas Kriteria Kualitas Tidur dan Tingkat Dismenore Primer

\begin{tabular}{ccc}
\hline Kriteria & $\begin{array}{c}\text { Jumlah Sampel (n) } \\
\text { n=106 }\end{array}$ & $\begin{array}{c}\text { Persentase } \\
\mathbf{\%}\end{array}$ \\
\hline Kualitas tidur & 66 & 62 \\
Buruk & 40 & 38 \\
Baik & & \\
$\begin{array}{c}\text { Dismenore } \\
\text { primer }\end{array}$ & 43 & 41 \\
Ringan & 52 & 49 \\
Sedang & $\mathbf{1 1}$ & 10 \\
Berat & skor kualitas tidur buruk: $\geq 7$, kualitas tidur \\
Keterangan: & baik: <7, ringan 1-3, sedang 4-6, berat 7-10
\end{tabular}

Tabel di bawah ini menunjukkan hubungan antara kualitas tidur dan dismenore primer dari mahasiswi yang telah diteliti.

Tabel 2 Hubungan Kualitas Tidur dengan Angka Kejadian Dismenore Primer

\begin{tabular}{lccccc}
\hline \multirow{2}{*}{$\begin{array}{l}\text { Dismenore } \\
\text { Primer }\end{array}$} & \multicolumn{4}{c}{ Kualitas Tidur } & \multirow{2}{*}{ Total } \\
\cline { 2 - 5 } & \multicolumn{2}{c}{ Buruk } & \multicolumn{2}{c}{ Baik } & \\
\cline { 2 - 5 } & n & \% & n & \% & \\
\hline Ringan & 19 & 44 & 24 & 56 & 43 \\
Sedang & 38 & 73 & 14 & 27 & 52 \\
Berat & 9 & 80 & 2 & 18 & 11 \\
\hline
\end{tabular}

Subjek dengan kualitas tidur buruk, angka kejadian dismenore primer sedang dan berat semakin tinggi (44\%, 73\%, dan 80\%; Tabel 2).

Selanjutnya, untuk menghitung hubungan statistik tabel di atas diubah menjadi tabel 2x2 seperti di bawah ini.

Tabel 3 Hubungan Kualitas Tidur dengan Subjek Dismenore Primer Sedang

\begin{tabular}{lcccccc}
\hline \multirow{2}{*}{$\begin{array}{c}\text { Kualitas } \\
\text { Tidur }\end{array}$} & \multicolumn{3}{c}{ Dismenore Primer } & & \multirow{2}{*}{ Sedang } & \multicolumn{2}{c}{ Ringan } & Total & Nilai p \\
\cline { 2 - 5 } & $\mathbf{n}$ & $\mathbf{\%}$ & $\mathbf{n}$ & $\mathbf{\%}$ & & \\
\hline Buruk & 38 & 73 & 19 & 44 & 57 & \multirow{2}{*}{0,008} \\
Baik & 14 & 27 & 24 & 56 & 38 & \\
\hline
\end{tabular}

Pada Tabel 3 tampak bahwa dismenore primer sedang lebih besar pada kualitas tidur buruk dibanding dengan kualitas tidur baik. Secara statistik perbedaan ini sangat bermakna $(\mathrm{p}=0,008)$.

Tabel 4 Hubungan Kualitas Tidur dengan Subjek Dismenore Primer Berat

\begin{tabular}{|c|c|c|c|c|c|c|}
\hline \multirow{3}{*}{$\begin{array}{c}\text { Kualitas } \\
\text { Tidur }\end{array}$} & \multicolumn{4}{|c|}{ Dismenore Primer } & \multirow{3}{*}{ Total } & \multirow{3}{*}{ Nilai p } \\
\hline & \multicolumn{2}{|c|}{ Berat } & \multicolumn{2}{|c|}{ Ringan } & & \\
\hline & $\mathbf{n}$ & $\%$ & $\mathbf{n}$ & $\%$ & & \\
\hline \multirow{2}{*}{$\begin{array}{c}\text { Buruk } \\
\text { Baik }\end{array}$} & 9 & 82 & 19 & 44 & 28 & \multirow{2}{*}{0,04} \\
\hline & 2 & 18 & 24 & 56 & 26 & \\
\hline
\end{tabular}

Keterangan: Uji Eksak Fisher
Kejadian dismenore primer berat lebih besar pada kualitas tidur buruk dibanding dengan kualitas tidur baik. Secara statistik perbedaan ini bermakna $(p=0,04$; Tabel 4).

\section{Pembahasan}

Berdasar atas tinjauan dari literatur kuesioner dan penelitian sebelumnya, kualitas tidur diidentifikasi sebagai inisiasi tidur, pemeliharaan tidur, kedalaman tidur, mimpi, bangun setelah tidur, serta kondisi setelah tidur yang berpengaruh pada kehidupan seharihari, jumlah tidur, dan kepuasan tidur. ${ }^{14}$ Dari hasil penelitian, kualitas tidur buruk paling banyak dialami oleh mahasiswi Fakultas Kedokteran Universitas Islam Bandung yang menjadi subjek penelitian, yaitu dari 106 mahasiswi, 66 mahasiswi (62\%) memiliki kualitas tidur buruk. Jumlah yang mengalami kualitas tidur baik jauh lebih rendah, yaitu 40 mahasiswi (38\%) sehingga dapat dikatakan mahasiswi Fakultas Kedokteran Universitas Islam Bandung mengalami kualitas tidur buruk.

Hasil ini serupa dengan penelitian yang dilakukan oleh Rivhan ${ }^{17}$ tentang gambaran kualitas tidur pada mahasiswa fakultas kedokteran. Hasil penelitian itu menunjukkan dari 100 mahasiswa, 51 mahasiswa (51\%) memiliki kualitas tidur buruk. Berdasar atas jenis kelamin, kualitas tidur buruk lebih sering terjadi pada perempuan (28\%) daripada laki-laki. Durasi tidur yang pendek dapat memengaruhi kualitas tidur responden. Dalam kuesioner PSQI terdapat komponen durasi tidur. Hasil penelitian menunjukkan mayoritas durasi tidur responden hanya tidur selama kurang dari 5 jam pada malam hari dan hanya sedikit responden yang tidur selama lebih dari 7 jam pada malam hari. Kementrian Kesehatan Republik Indonesia menyatakan bahwa usia dewasa muda hingga dewasa tua (18-40 tahun) membutuhkan waktu tidur 7-8 jam pada malam hari. ${ }^{18}$

Dismenore primer adalah menstruasi yang menyakitkan terkait dengan pelepasan prostaglandin dalam siklus ovulasi, tetapi tidak disertai dengan penyakit pelvis. ${ }^{19}$ Menurut Mahmudiono 2011 yang dikutip dari Purba dkk. ${ }^{20}$ angka kejadian dismenorea primer pada remaja wanita usia 14-19 tahun di Indonesia sekitar 54,89\%. Dismenore primer sedang paling banyak dialami oleh mahasiswi Fakultas Kedokteran Universitas Islam Bandung yang menjadi subjek penelitian. Hal tersebut dapat dilihat dari jumlah subjek yang mengalami dismenore primer berat, yaitu sebanyak 10 orang (10\%) sedangkan yang mengalami dismenore primer sedang 52 (49\%) dan ringan 43 orang (41\%). Perbedaan antara subjek yang mengalami dismenore primer ringan dan berat cukup tinggi, tetapi subjek yang mengeluhkan dismenore primer sedang dan berat jumlahnya tidak jauh berbeda. Hasil penelitian ini serupa dengan penelitian yang dilakukan oleh Savitri ${ }^{2}$ yang dilakukan pada remaja dengan hasil bahwa gambaran skala nyeri haid yang dialami oleh mahasiswi sebagian besar berada pada rentang nyeri haid ringan 6 siswi $(11,8 \%)$, sedang 38 orang siswi $(74,5 \%)$, dan berat 6 siswi $(11,8 \%)$. Menurut Wahyu dkk. yang dikutip dari Savitri, ${ }^{2}$ penelitian ini membuktikan bahwa hampir sebagian 
besar siswi ketika sedang menstruasi mengalami nyeri (dismenore) dalam rentang skala nyeri sedang. Hal ini disebabkan oleh saat proses menstruasi memasuki fase sekresi, maka uterus akan mengeluarkan hormon prostaglandin yang akan mengakibatkan hiperaktivitas miometrium. Ketika terjadi hiperaktivitas miometrium uterus akan mengalami ischemia jaringan dikarenakan aliran darah tidak lancar akibat prostaglandin yang berlebihan tersebut. ${ }^{2}$

Hubungan kualitas tidur dengan dismenore primer dibahas dalam dua skenario yang berbeda pada tabel hasil analisis data. Pertama, tabulasi silang antara kualitas tidur dan dismenore primer dibuat dengan menggunakan tiga kategori dismenore (ringan, sedang, berat) dan dua kategori kualitas tidur (baik, buruk). Kemudian dilakukan analisis terhadap tabulasi silang antara dua kategori kualitas tidur dan dua kategori dismenore primer. Pada skenario kedua, kategori ringan selalu dilibatkan baik dalam dismenore primer. Hal ini disebabkan oleh kategori ringan dijadikan pembanding bagi kategori lainnya. Pada skenario kedua dilakukan uji chi-square untuk menguji apakah terdapat hubungan yang signifikan secara statistik antara kualitas tidur dan dismenore primer.

Pada penelitian ini kelompok subjek mengalami kualitas tidur buruk, subjek yang mengalami dismenore primer ringan sebanyak 19 orang (44\%), dismenore primer sedang 38 orang (73\%), dan dismenore primer berat 9 orang (82\%). Subjek dengan kualitas tidur buruk kebanyakan mengalami dismenore primer ringan dan sedang. Kelompok penelitian dengan kualitas tidur baik, subjek yang mengalami dismenore primer ringan 24 orang (56\%), dismenore primer sedang 14 orang (27\%), dan dismenore primer berat 2 orang (18\%). Subjek dengan kualitas tidur baik kebanyakan mengalami dismenore primer ringan. Simpulan hasil uji tersebut semakin buruk kualitas tidur maka angka kejadian dismenore semakin tinggi. Secara statistik hubungan ini bermakna.

Terdapat hubungan yang sangat bermakna antara kualitas tidur dan dismenore primer (ringan dan sedang). Terdapat hubungan yang bermakna antara kualitas tidur dan dismenore primer (ringan dan berat).

Hasil penelitian tersebut serupa dengan hasil penelitian yang dilakukan Yudhanti ${ }^{21}$ bahwa terdapat hubungan signifikan antara kualitas tidur dan kejadian dismenore. Individu dengan kualitas tidur yang buruk ditandai dengan kurang memiliki waktu tidur yang cukup, tidak larut malam, sulit bangun tepat waktu, mengalami gangguan tidur, serta suka terbangun di sela-sela waktu tidur. Pada penelitian ini mahasiwi fakultas kedokteran sebagian besar memiliki kualitas tidur buruk. Menurut Hertz ${ }^{22}$ kualitas tidur dapat dipengaruhi oleh beberapa faktor. Salah satunya faktor hormonal, sindrom nyeri, dan juga masalah psikologis, terutama depresi merupakan beberapa faktor yang memengaruhi kualitas tidur pada wanita. Secara umum, hormon seks memainkan peran dalam menyebabkan gangguan tidur pada wanita, baik dengan efek langsung pada proses tidur atau pada efek lainnya, seperti pada suasana dan keadaan emosional. Hormon seks itu memengaruhi elektroensefalografik selama fase luteal dengan meningkatkan frekuensi elektroensefalografik dan suhu tubuh inti selama tidur. ${ }^{22}$

Penelitian terkait kualitas tidur pada penderita nyeri telah banyak dilaksanakan, seperti penelitian yang dilakukan oleh Haack dkk. ${ }^{23}$ terhadap relawan yang sehat, pengurangan tidur hingga 4 jam dapat meningkatkan prostaglandin sebagai mediator nyeri dan bioavaibilitas agen-agen inflamasi seperti interleukin-6 (IL-6) dan tumor necrosis factor alpha (TNF- $\alpha$ ) yang merupakan pencetus nyeri yang poten. Smith dkk. ${ }^{24}$ juga melakukan penelitian efek kurang tidur terhadap inhibisi nyeri dan nyeri spontan pada wanita, didapatkan hasil bahwa gangguan tidur secara terus-menerus dapat merusak fungsi penghambatan nyeri endogen dan meningkatkan nyeri spontan. Selain itu, juga dapat mendukung peran patofisiologi yang mungkin dari gangguan tidur pada nyeri kronis.

\section{Simpulan}

Sebagian besar mahasiwi Fakultas Kedokteran (FK) Universitas Islam Bandung memiliki kualitas tidur buruk dan dismenore sedang. Semakin buruk kualitas tidur, maka angka kejadian dismenore semakin tinggi.

\section{Ucapan Terima kasih}

Ucapan terima kasih penulis sampaikan kepada responden mahasiswi tingkat 3 Fakultas Kedokteran (FK) Universitas Islam Bandung.

\section{Daftar Pustaka}

1. Bozzuto G, Ruggieri PAM. Risk factor for dysmenorrhea among young adult female university students. Ann Ist Super Sanità. 2016;52(1):93-103.

2. Savitri R. Gambaran skala nyeri haid pada usia remaja. J Keperawatan Aisyiyah. 2015;2:9-25.

3. Omidvar S, Bakouei F, Amiri FN, Begum K. Primary dysmenorrhea and menstrual symptoms in indian female students: prevalence, impact and management. Glob J Health Sci. 2016;8(8):13544.

4. Hailemeskel S, Demissie A, Assefa N. Primary dysmenorrhea magnitude, associated risk factors, and its effect on academic performance: evidence from female university students in Ethiopia. Int $\mathrm{J}$ Womens Health. 2016;8:489-96.

5. Berkley KJ. Dismenorrea primaria: una necesidad urgente. Pain Clin Updat. 2013;11(1):1-8.

6. Nissa DNZ, Ekowati RAR, Tresnasari C. Hubungan antara indeks massa tubuh dengan kejadian dismenore primer pada mahasiswi kedokteran Unisba tingkat 1 tahun 2016. Prosiding Pendidikan Dokter. 2016;2(1):805-10.

7. Ju H, Jones M, Mishra G. The prevalence and risk factors of dysmenorrhea. Epidemiol Rev. 2014;36(1):104-13

8. Andriyani S, Sumartini S, Afifah VN, Madya R. Gambaran pengetahuan remaja madya $\left(13^{-15}\right.$ tahun) tentang dysmenorrhea di SMPN 29 
Kota Bandung. J Pend Keperawatan Indonesia. 2016;2(2):115-21.

9. Mahvash N, Eidy A, Mehdi K, Zahra MT, Mani M, Shahla H. The effect of physical activity on primary dysmenorrhea of female university students. World Appl Sci J. 2012;17(10):1246-52.

10. Gebeyehu MB, Mekuria AB, Tefera YG, Andarge DA, Debay YB, Bejiga GS, dkk. Prevalence, impact, and management practice of dysmenorrhea among University of Gondar students, Northwestern Ethiopia: a cross-sectional study. Int J Reprod Med. 2017;2017:3208276. doi: 10.1155/2017/3208276. Epub 2017 May 14.

11. Maryland Title X Family Cillica Guidelines. Cervical cytology and management of abnormal cervical cytology - Revised January 2017 Page 1 of 10. 2017 January:1-10. Tersedia dari: https://phpa.health.maryland.gov/mch/ Documents/Family_Planning_Guidelines/2017/ Gynecologic_Services/Cervical\%20Cytology\%20 and \% $20 \mathrm{Man}$ a ement $\% 20 \mathrm{Abnromal} \% 20$ Cytology,\%202017.pdf.

12. Iacovides S, Avidon I, Baker FC. What we know about primary dysmenorrhea today: a critical review. Hum Reprod Update. 2015;21(6):762-78.

13. Finan PH, Goodin BR, Smith MT, Hopkins J. The association of sleep and pain: An update and a path forward. J Pain. 2013;14(12):1539-52.

14. Yi H, Shin K, Shin C. Development of the sleep quality Scale. J Sleep Res. 2006 Sep;15(3):309-16.

15. Azad MC, Fraser K, Rumana N, Abdullah AF, Shahana N, Hanly PJ, dkk. Sleep disturbances among medical students: a global perspective. J Clin Sleep Med. 2015 Jan 15;11(1):69-74.

16. Woosley JA, Lichstein KL. Dysmenorrhea, the menstrual cycle, and sleep. Behav Med. 2014 Jan 10;40(1):14-21.
17. Rivhan Fuzan. Gambaran kualitas tidur pada mahasiswa Fakultas Kedokteran Universitas Sumatera Utara tahun Akademik 2013/2014. (diunduh 12 Maret 2018); Tersedia dari: https:// text-id.123dok.com/document/1y992wyggambaran-kualitas-tidur-pada-mahasiswafakultas-kedokteran-universitas-sumatera-utaratahun-akademik-2013-2014.html

18. Kementrian Kesehatan Republik Indonesia. Kebutuhan tidur sesuai usia. Jakarta: Kemenkes RI; 2015.

19. McCance KL. Pathophysiology: the biologic basis for disease in adults and children. Edisi ke-6. St. Louis, Missouri. Mosby; 2009.

20. Purba FS, Sarumpaet SM, Jemadi. Faktor-faktor yang berhubungan dengan dismenore pada siswi SMK Negeri 10 Medan tahun 2013. GKRE. 2015;2(5):1-10.

21. Yudhanti MD. Hubungan kualitas tidur dengan kejadian dismenore primer pada mahasiswi Fakultas Kedokteran Universitas Sebelas Maret. (diunduh 15 April 2018); Tersedia dari: https:// digilib.uns.ac.id/dokumen/detail/42907/ Hubungan-kualitas-tidur-dengan-kejadianDismenore-primer-pada-mahasiswi-FakultasKedokteran-Universitas-Sebelas-Maret

22. Gila Hertz. Sleep dysfunction in women. PLoS One. 201AD Mar 28;1.

23. Haack M, Sanchez E, Mullington JM.. Elevated inflammatory markers in response to prolonged sleep restriction are associated with increased pain experience in healthy volunteers. Sleep. 2007 Sep;30(9):1145-52.

24. Smith MT, Edwards RR, McCann UD, Haythornthwaite JA. The effects of sleep deprivation on pain inhibition and spontaneous pain in women. Sleep. $2007 \mathrm{Apr} ; 30(4): 494-505$. 